\title{
Farm-based day care in Norway - a complementary service for people with dementia
}

This article was published in the following Dove Press journal: Journal of Multidisciplinary Healthcare

\section{Tanja Louise Ibsen' \\ Siren Eriksen' \\ Grete Grindal Patil ${ }^{2}$}

'Norwegian National Advisory Unit on Ageing and Health, Vestfold Hospital Trust, Tønsberg, Norway; ${ }^{2}$ Department of Public Health Science, Faculty of Landscape and Society, Norwegian University of Life Sciences, Ås, Norway
Correspondence: Tanja Louise Ibsen Norwegian National Unit on Ageing and Health, Vestfold Hospital Trust, Post box 2136, Tønsberg 3103, Norway

Tel +47958 8I 287

Email tanja.ibsen@aldringoghelse.no
Background: Day care services provide meaningful activities and coping experiences in a safe environment for people with dementia, as well as improve quality of life. Such services vary in types and settings. Farm-based day care (FDC) services are described as services that have been adapted from the farm setting, using farm resources to promote health. There is limited knowledge on the service offered in both FDC and regular day care services for people with dementia. The present study aims to investigate FDC in Norway and describe the services and the participants' care environment.

Materials and methods: We mapped the existing farms offering day care in Norway by the spring $2017(\mathrm{~N}=33)$ and collected information through two cross-sectional surveys $(\mathrm{N}=32)$ answered by the service providers at the farms.

Results: The farms included in this survey provided day care services to 227 people with dementia, located in most regions of Norway. The services varied in terms of group size and half of the services had young people with dementia ( $\leq 65$ years) and people with dementia at an early stage as their primary target group. About half of the staff had health care education (47.5\%), and there were staff with agricultural competence available in most FDCs. All farms reported that the participants spent time outdoors every day, and all services, except two, had animals. The providers highlighted the opportunity to choose activities that were individually tailored for each participant, as the diversity of resources in the farm made it possible to organize different activities.

Conclusion: FDC services have similarities in organization, daily structure, and number of health education personnel to other day care services, but differ in type of care environment with a wide range of activities and available resources like farm buildings, gardens, animals, and outdoor areas.

Keywords: green care, care farms, farm context, day care service, person-centered care

\section{Introduction}

Dementia is a progressive condition leading to loss of functions related to memory, orientation, and everyday life. In the severe stage of dementia, the patients will be fully dependent on others. ${ }^{1,2}$ Currently, approximately 47 million people are living with dementia worldwide, a number that is estimated to triple by $2050 .{ }^{3}$ More than 70,000 Norwegians are living with dementia today. ${ }^{4}$

Health services and support offered to people with dementia vary around the world depending on resources and priorities. The World Health Organization recommends that all countries should develop national approaches in response to the impact of dementia. $^{2}$ In Norway, $\sim 60 \%-65 \%$ of people with dementia are living in their own homes, 
either alone or together with family members. ${ }^{1}$ In most cases, a family member will be the main caregiver. Many people with dementia wish to remain living in their own home, and they may often be in need of community services, including day care services. . $^{2,5,6}$

Day care services are meant to provide meaningful activities and coping experiences in a safe environment for people with dementia, as well as improve their quality of life. ${ }^{4}$ These services should also serve as a respite for family caregivers, and it is claimed that such services may delay nursing home placement. ${ }^{4,7-9}$ A recent Norwegian study found higher self-reported quality of life among people with dementia attending day care services compared to those not receiving day care. ${ }^{10}$ By 2020, all Norwegian municipalities will be obliged to offer day care to people with dementia. The national action plan for dementia, Dementia plan 2015, welcomes a variation in types and settings of day care services such as those offered by care farms. ${ }^{11}$ A manual for farm-based day care (FDC) service has been prepared as a part of the strategy. ${ }^{12}$ Furthermore, people with dementia are also a prioritized target group in the Norwegian action plan for care farming. ${ }^{13}$

Care farm services, like FDC, are described as services that use farm resources like the agricultural landscape and farming activities to promote mental and physical health for different target groups. ${ }^{13,14}$ The services are a collaboration between farmers, health and social workers, and participants. ${ }^{14}$ In Norway, the municipalities pay for the service taking place at private farms, and FDC is thereby a collaboration between a private enterprise and a municipality. By Norwegian law, the municipality is responsible for providing health and social services. ${ }^{4} \mathrm{FDC}$ is offered in several countries, but organized in different ways. In some countries, FDC is linked to a health care institution with limited agricultural production (Germany), while other countries offer day care services located on productive agricultural farms (the Netherlands and Norway). ${ }^{15}$ FDC for people with dementia has been offered in Norway since the early 2000s, ${ }^{16}$ and a survey in 2014 revealed that 40 care farms provided FDC for people with dementia. ${ }^{17}$

In addition to people with dementia, care farming services in Norway cover a huge variety of target groups: the largest ones comprise educational programs for schoolchildren and vocational services for out-of-work adults or those with mental health problems. Norwegian research on vocational care farming services indicates that such settings are associated with improvements in mental health, coping, and social support experience. ${ }^{18}$ Such findings are in line with international research describing care farm services as empowermentoriented and coping-based, and highlight elements such as social support and inclusion in a group, meaningful activities, a homelike environment, small-scale setting, and the farmer as important. ${ }^{14,19-21}$ Leck et al emphasized that the range of resources at care farms provides a good environment for supporting the attendee's well-being. ${ }^{22}$ Also, Hemingway et al found that FDC promotes well-being by providing an inclusive environment enabling the participants to connect with themselves and nature. This contributes to the attendant's personal growth and autonomy. ${ }^{23}$

There is limited knowledge on both farm-based and regular day care (RDC) services for people with dementia. However, recent Norwegian qualitative studies found that attending RDC services contributed to the maintenance of structure, social stimulation, and activities in everyday life. ${ }^{9,24}$ The participants highlighted the importance of good meals together with others and the opportunity to go for a walk. They also underlined the possibility to choose whether they wanted to join an activity or not. Studies from the Netherlands have compared activities at care farms and RDC services for people with dementia. They found that activities at care farms were more frequently available and more individually tailored. Furthermore, the participants at care farms spent more time being active outdoors. ${ }^{21,25,26}$

To meet the Norwegian government's request for quality development of care services for people with dementia, and day care services in particular, there is a need to uncover the nature of the various available services to understand their potential in dementia care. The present study aims to contribute to this by mapping the available FDCs for this target group in Norway by 2017 and describe the services and the participants' care environment. We have addressed the following questions:

1. How is the FDC organized?

2. What are the characteristics of the farm environment in the FDC?

3. Which activities are taking place at a FDC?

4. What is done for individual facilitation in the FDC?

\section{Methods}

We collected information about the care farms and their day care services through two cross-sectional surveys conducted in all farms offering FDC in Norway. A survey by Gjøra et al in 2015 was the starting point for locating farms offering FDC for people with dementia in Norway. ${ }^{17}$ We further searched for farms with active services through professional 
care farm services, websites of potential farms, staff at the county governor's agricultural sections, as well as snowballing among those already accounted for. Finally, by January 2017, a total of 33 farms throughout Norway had confirmed to us that they were offering day care services to people with dementia. Despite the rather transparent recruitment process, we learned about one more farm with FDC in April 2017 and this farm was not included in our study.

The main survey was conducted from January to March 2017 and addressed questions with specific response options on the organization of the services, the people with dementia attending the day care, the employees, the farm environment, and the activities conducted at the farm. A description of the organization of a normal day was noted as free text. Thirtytwo farmers answered the main survey.

The FDC providers were interviewed by telephone $(n=26)$ or face-to-face $(n=6)$. The FDC providers were offered the questionnaire through e-mail beforehand so that they had the option of reading the questions before the interview. An additional web-based survey conducted in January 2017 through Quest Back provided the study with business information about the farm and knowledge about farm activities. For this survey, only 23 of three 32 FDC providers participated. The size of the municipalities where the FDCs were located was classified according to Langørgen et al. ${ }^{27}$

We used descriptive analysis to describe the characteristics of the FDCs. The free text contained short sentences and keywords describing a normal day. The text was analyzed by reading the text several times before groups with common themes were identified. In addition, we compared our findings with data on RDC services in Norway ${ }^{17}$ in order to identify the differences.

\section{Ethics}

The study was approved by The Norwegian Centre for Research Data (no. 49799). In the main cross-sectional survey, all the respondents gave their oral consent to participate at the time the researcher called to inform them about the study and asked for their participation. For the additional survey, the farmers gave their consent to participate by answering the Quest Back.

\section{Results}

We located FDCs in 29 Norwegian municipalities, representing $6.8 \%$ of all the municipalities in the country, and the 32 FDCs represent an estimated 7\% of all day care services in Norway in 2017 (Table 1). The FDCs are located in most
Table I Comparison between farm-based day care (FDC) and regular day care $(\mathrm{RDC})$ in Norway

\begin{tabular}{|c|c|c|}
\hline Variable & FDC & $\mathbf{R D C}^{\mathbf{a}}$ \\
\hline Number of day care services & 32 & $45 I^{b}$ \\
\hline Number of municipalities with day care ${ }^{c}(\%)$ & $29(6.8)$ & $305(71.3)$ \\
\hline Number of participants in total & 227 & 6318 \\
\hline Average number of participants per day & 5 & 6.3 \\
\hline $\begin{array}{l}\text { Average number of days per week with day } \\
\text { care service }\end{array}$ & 2.8 & 3.6 \\
\hline $\begin{array}{l}\text { Average number of participants per } \\
\text { employee }\end{array}$ & 2.3 & 3.5 \\
\hline Average hours per day & 5.3 & 5.7 \\
\hline $\begin{array}{l}\text { Number of services with day care for young } \\
\text { participants (\%) }\end{array}$ & $9(28.1)$ & $54^{\mathrm{d}}(12.0)$ \\
\hline \multicolumn{3}{|l|}{$\begin{array}{l}\text { Number of day care services with health- } \\
\text { educated personnel (\%) }\end{array}$} \\
\hline Regular nurse & $17(53.1)$ & $169(37.5)$ \\
\hline Health-educated personnele & $25(78.1)$ & $431(95.6)$ \\
\hline $\begin{array}{l}\text { Number of day care services with volunteer } \\
\text { workers }\end{array}$ & $20(62.5)$ & $163(36.1)$ \\
\hline
\end{tabular}

Notes: ${ }^{2}$ The data on regular day care are from 2014.17 bIncluding FDCs in 2014. 'Total number of municipalities was 426 in 2017 and 428 in 2014. dEleven of these

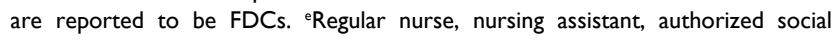
educator, occupational therapist.

regions in Norway, with the highest number of farms in the central and south-eastern part. In some small $(<5000$ inhabitants) and medium-sized (5000-20,000 inhabitants) municipalities, FDC is the only day care offered to people with dementia. With three exceptions, the farms with FDC typically had agricultural production. Based on income information for 23 farms, $83 \%$ had more than $50 \%$ of their total income from farm production or funding sources other than the FDC. Six FDCs offered welfare services to other target groups, e.g., schoolchildren or groups in need of vocational training, in parallel with the service for people with dementia. Some FDCs had other groups than people with dementia on separate days.

\section{Organization of the FDCs Target group}

The 32 FDCs included in this survey provided day care services to a total of 227 people with dementia (Table 2). To best describe the social care environment, we divided the FDCs into three categories according to the number of participants attending the services each day (Table 2); small groups with 1-3 participants each day, medium groups with 4-6 participants, and large groups with 7-10 participants. On average, FDCs with small, medium, and large groups offered services for 2, 3, and 4 days a week, respectively. However, there were variations from these average numbers, 
Table 2 Characteristics of included farm-based day care (FDC) according to group size of participants

\begin{tabular}{|c|c|c|c|c|}
\hline Variable & $\begin{array}{l}\text { Small groups } \\
\text { (I-3 participants) }\end{array}$ & $\begin{array}{l}\text { Medium groups } \\
\text { (4-6 participants) }\end{array}$ & $\begin{array}{l}\text { Large groups } \\
\text { (7-10 participants) }\end{array}$ & Total \\
\hline Number of farms & 7 & 19 & 6 & 32 \\
\hline Number of participants & 19 & $|4|$ & 67 & 227 \\
\hline Average number of participants per day & 2.29 & 5.33 & 7.67 & 5 \\
\hline Average total number of participant at each FDC (range) & $2.7 I(I-5)$ & $7.42(4-15)$ & $11.16(7-18)$ & 7.09 \\
\hline Average number of days per week with day care (range) & $2.00(I-3)$ & $2.63(I-5)$ & $3.67(2-5)$ & 2.76 \\
\hline Average number of participants per employee & 1.45 & 2.53 & 2.88 & 2.28 \\
\hline \multicolumn{5}{|l|}{ Different target groups ${ }^{\text {a }}$ number of FDCs } \\
\hline \multicolumn{5}{|l|}{ (age range of participants, years) } \\
\hline Young participants & I (75-85) & $6(50-85)$ & $2(53-87)$ & 9 \\
\hline Participants in early stage of dementia & $3(79-90)$ & $6(57-87)$ & $4(53-89)$ & 13 \\
\hline People with dementia in general & $3(62-80)$ & $11(59-96)$ & $2(53-92)$ & 16 \\
\hline \multicolumn{5}{|l|}{ Personnel with health education; number of FDCs (\%) } \\
\hline Regular nurse & $2(29)$ & $9(47)$ & $6(100)$ & $17(53)$ \\
\hline Health-educated personnel ${ }^{b}$ & $2(29)$ & $17(89)$ & $6(100)$ & $25(78)$ \\
\hline \multicolumn{5}{|c|}{ Personnel with other relevant competencies; number of FDCs (\%) } \\
\hline Pedagogical education ${ }^{c}$ & $2(29)$ & $2(I I)$ & 0 & $4(13)$ \\
\hline Health-related education ${ }^{d}$ & I (14) & 0 & 0 & I (14) \\
\hline Agricultural competence ${ }^{\mathrm{e}}$ & $7(100)$ & $14(74)$ & $5(83)$ & $26(8 I)$ \\
\hline Volunteer workers & $3(42)$ & $13(68)$ & $4(67)$ & $20(63)$ \\
\hline Students & $3(42)$ & $14(73)$ & $4(67)$ & $21(66)$ \\
\hline
\end{tabular}

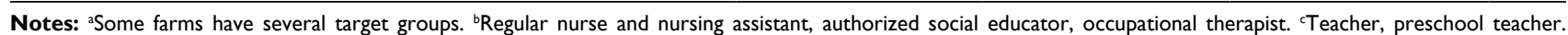
${ }^{d}$ Nutritionist, assistant occupational therapist. ${ }^{~}$ Formal and informal agricultural competence.

for example, among the FDCs with medium group size, four farms offered services only once a week.

More than half of the FDCs in our study $(\mathrm{N}=19)$ had young people with dementia $(\leq 65)$ and/or people with dementia at an early stage as their primary target group. The remaining FDCs $(\mathrm{N}=13)$ included people with dementia in general. Compared to RDC services, FDC services more often prioritize young people or people in an early stage of dementia (Table 1). For all FDCs, the municipal health care unit was responsible for assigning the day care services to people with dementia. For 18 of the FDCs, this was done in collaboration with the service provider in the farm. For the remaining 14 FDCs, the municipality selected participants on their own.

\section{Daily routines in the FDCs}

A typical day in the FDC usually started between 9:00 a.m. and 10:00 a.m. and ended between 14:00 p.m. and 15:30 p.m. The average operating hours were 5.3 hours. Most FDCs served three meals each day; breakfast at arrival, lunch/coffee break, and dinner before the day ended. Between the meals, there were indoor or outdoor activities. All the service providers reported that the participants spent time outdoors every day, which varied between 1 hour and 4 and a half hours during summer, and between half an hour and 4 hours in winter (Table 3 ). The participants were brought back and forth by car or minibus, either by the provider (18 farms) or by minibus or taxi arranged by the municipality (14 farms).

\section{Personnel and competence}

All the FDCs in this study were run in collaboration between the municipality and the farmer, and in general, the municipality had the overall responsibility for the quality of the service. At the majority of the FDCs, the farmer living on his or her farm provided the day care service on a daily basis, often in collaboration with additional employees. In two farms, FDCs were run by municipal employees only, and the farm and its resources were at the disposal of the FDC.

About half of the staff in the FDCs had health care education (47.5\%). Eighty-nine percent of the medium-sized FDCs had health care personnel in the staff, and all FDCs with large group sizes had at least one employee with health education (Table 3). In the FDCs with medium group sizes, there were on average three participants with dementia per employee at the farm. The small farms had a high share of employees per participant, as some of the farms had two to three participants and two employees. However, the small 
Table 3 Locations of outdoor activity and time spend outdoors in relation to group size in the farm-based day care (FDC)

\begin{tabular}{|c|c|c|c|c|}
\hline & $\begin{array}{l}\text { Small groups } \\
\text { (I-3 participants) } \\
(\mathrm{N}=7)\end{array}$ & $\begin{array}{l}\text { Medium groups } \\
\text { (4-6 participants) } \\
(\mathrm{N}=19)\end{array}$ & $\begin{array}{l}\text { Large groups } \\
(7-10 \text { participants) } \\
(\mathrm{N}=6)\end{array}$ & $\begin{array}{l}\text { Total } \\
(\mathrm{N}=32)\end{array}$ \\
\hline \multicolumn{5}{|c|}{ Location for outside activity; number of FDC (\%) } \\
\hline Yard/garden & $7(100)$ & $19(100)$ & $6(100)$ & $32(100)$ \\
\hline Greenhouse & $2(29)$ & $10(53)$ & 0 & $12(38)$ \\
\hline Production soil & $3(43)$ & $7(37)$ & $4(67)$ & $14(44)$ \\
\hline Own uncultivated land & $3(43)$ & $17(89)$ & $5(83)$ & $25(78)$ \\
\hline Others' uncultivated land & $4(57)$ & $19(100)$ & $6(100)$ & $29(91)$ \\
\hline Forest & $5(7 I)$ & $17(89)$ & $6(100)$ & $28(88)$ \\
\hline Lake/beach & $4(57)$ & $14(73)$ & $5(83)$ & $23(72)$ \\
\hline Workshop & $4(57)$ & $6(37)$ & $6(100)$ & $16(50)$ \\
\hline Barn & $2(29)$ & $12(63)$ & $5(83)$ & $19(59)$ \\
\hline Shed & $5(7 I)$ & $13(68)$ & $3(50)$ & $21(66)$ \\
\hline Stable & $2(29)$ & $7(37)$ & $3(50)$ & $12(35)$ \\
\hline \multicolumn{5}{|c|}{ Average time spent outdoors; $\mathrm{h}$ (range) } \\
\hline Summer & $2.86(1-4.5)$ & $2.88(1-4.5)$ & $2.92(2.5-3.5)$ & 2.88 \\
\hline Winter & $1.50(0.5-4)$ & $1.04(0.5-2.5)$ & $1.83(I-2.5)$ & 1.45 \\
\hline
\end{tabular}

groups did not have the same level of health personnel as the other two groups. If we compare with RDC, there is a higher coverage of regular nurses in FDC. However, there are more employees with other health education in RDC (Table 1).

There was also staff with agricultural competence available in most FDCs $(n=26)$, either through formal education or through skills acquired by managing the farm for many years. Furthermore, students and volunteer workers were often present in the FDCs. While some farms scheduled the use of volunteers on a regular basis, other farms invited volunteer workers as needed for help with different activities, e.g., small excursions/trips and when doing crafts.

\section{The farm environment}

The farms often had several buildings at the yard. The diversity of the built environment made up the physical context for the rationale of FDCs along with the agricultural land and nature areas belonging to the farm, neighbor farms, or land owned by the local community. Most FDCs reported having a separate building at the farm dedicated to day care purposes. Only four of the services took place in the farmer's own house. All farms in the study reported that the participants spent time at the yard or in a garden (Table 3 ). In addition to using the farm buildings and adjacent outdoor areas, many reported using their own or others uncultivated farmland, the nearby forest, or lake.

All FDCs, except two, had animals in the farm. Twentynine farms had one or more types of farm animals such as poultry, sheep, cattle, pigs, and goats, and 22 of these farms reported that they had animals for meat or milk production. Five FDCs offering services to medium (4) and large (1) group sizes reported that the participants did not get to be in direct contact with some of the production animals (e.g., poultry) due to production rules. Three FDCs had only cats or dogs.

\section{Activities}

It was evident from the free text that the season of the year influenced which activities took place at the farm. The most common activities in FDCs were going for a walk outside and social interaction indoors (Table 4). Indoor activity was often related to meals. Activities related to music and singing, preparing food, making crafts, and playing games were also common. Many of the providers also described reading (mainly newspapers and stories) as a normal activity.

Farm activities involving work with plants, including flowers, fruits, and vegetables, occurred at $90 \%$ of the FDCs, and farm-related activities like woodworking were reported to require a lot of time. Seventy-eight percent of the farms included animal-related activities in their services. Many providers reported that such activities often consisted of chopping and preparing food, feeding the animals, or just watching them during the day.

\section{Individual facilitation}

All the providers highlighted the opportunity to choose activities that are individually tailored for each participant, as the diversity of resources in the farm made it possible to 
Table 4 Commonly reported activities and time spend outdoors in farm-based day care (FDC) according to different group sizes of participants

\begin{tabular}{|c|c|c|c|c|}
\hline Type of activity; number of FDC (\%) & $\begin{array}{l}\text { Small groups } \\
\text { (I-3 participants) } \\
(\mathrm{N}=7)\end{array}$ & $\begin{array}{l}\text { Medium groups } \\
\text { (4-6 participants) } \\
(\mathrm{N}=19)\end{array}$ & $\begin{array}{l}\text { Large groups } \\
(7-10 \text { participants) } \\
(\mathrm{N}=6)\end{array}$ & $\begin{array}{l}\text { Total } \\
(\mathrm{N}=32)\end{array}$ \\
\hline Walking outside & $7(100)$ & $19(100)$ & $6(100)$ & $32(100)$ \\
\hline Social interaction indoor & $7(100)$ & $19(100)$ & $6(100)$ & $32(100)$ \\
\hline Plant activities ( $\mathrm{N}=29)$ & $7(100)$ & $16(88)$ & $6(100)$ & $29(100)$ \\
\hline Music and singing & $5(7 I)$ & $19(100)$ & $6(100)$ & $30(94)$ \\
\hline Making food & $5(7 I)$ & $18(95)$ & $4(67)$ & $27(84)$ \\
\hline Other farm work $(\mathrm{N}=30)$ & $6(86)$ & $14(82)$ & $5(83)$ & $25(83)$ \\
\hline Animal-related activity & $5(7 I)$ & $15(79)$ & $5(83)$ & $25(78)$ \\
\hline Play games $(\mathrm{N}=29)$ & $4(57)$ & $15(94)$ & $3(50)$ & $22(76)$ \\
\hline Crafts $(\mathrm{N}=30)$ & $5(7 I)$ & II (65) & $3(50)$ & $19(63)$ \\
\hline
\end{tabular}

organize different farm-related activities. Volunteer workers were often invited to facilitate the more flexible activities to meet individual needs. Furthermore, 22 FDCs reported that they had routines wherein they met with the person with dementia, the next of kin or both, when the person with dementia started in the FDC. Fifteen FDCs filled out a written document designed to gain knowledge about background and resources of the person with dementia, and all service providers had regular conversations with the participant, next of kin or both, focusing on the participant's well-being at the farm. More than $40 \%$ of the farms wrote a daily summary, which the participants could bring back home to their relatives. It was most common to have a combination of several of the abovementioned strategies to facilitate the service for the participants. Only two FDCs reported that dialogue with the participants as their only information source.

\section{Discussion}

The purpose of the present study was to describe the nature of FDC in Norway as a contribution to the discussion on quality development of day care services for people with dementia. More than $90 \%$ of the providers from the FDCs answered our main survey, and we believe that our data give a representative insight into this particular type of day care service.

We found a variation from a few small services (1-3 participants) to large services (7-10 participants), but with most services for 4-6 participants. In RDC in Norway, a common group size is 5-8 participants. ${ }^{17}$ FDCs with small, medium, and large group sizes were located in municipalities of different sizes and in most regions in Norway. All FDCs were assigned on behalf of the municipal health care system, and the participants were referred to the service through health care personnel. This reflects on the health care system in Norway and the municipalities' legal responsibility to provide such services to people with dementia, ${ }^{28}$ and no FDC in the study offered privately financed services. The farmer served as the main provider in most of the mapped FDCs. Further, since $83 \%$ of the farms still had more $50 \%$ of their income from other farm-related activities, this may indicate that the FDC was an integral part of ordinary farm life.

Two Dutch studies indicated that participants in FDC tend to be younger and more physically active than those attending RDC. ${ }^{21,29}$ Physical health has been emphasized as an important criterion for inclusion, as the participants must be able to go for walks and do easy farm work outdoors. ${ }^{30,31}$ A Norwegian study by Gjøra et al found that $9.5 \%$ of RDC services were customized to young people with dementia. ${ }^{17}$ In our study, nine of the 32 FDCs had young people with dementia ( $\leq 65$ years) as their main target group. Despite this, we found that the nine services had participants in a wide range of age: from 50 up to 87 years. This raises several questions: are there too few young people with dementia in the municipality? Is it difficult to recruit young people with dementia to day care services? Are they not interested in participating at a FDC? In a study of people with early onset dementia ( $<65$ years) Johannessen and Möller found that this group needed help to still be connected to others and the society. ${ }^{32}$ Many of their informants reported that being diagnosed with dementia was stigmatizing and that it often led to a loss in their sense of social cohesion with others. There are reasons to believe that young people with dementia prefer services tailored for this particular group, 
which are not located at a nursing home or settings connected to "being old". Most people with dementia are aged 75 years or older, ${ }^{3}$ but many young people with dementia still have a physical capacity to work in line with their age, though their cognitive capacity is reduced. ${ }^{32}$

We found that $78 \%$ of all the FDCs had personnel with health education. For the majority of farms (those with more than four participants), the number was $92 \%$. This is about the same as in RDC for people with dementia in Norway. ${ }^{17}$ However, among the small FDCs, only two of seven farms had health-educated personnel. In Norway, it is a requirement for health care services to have sufficient competence by being staffed with professional personnel. ${ }^{33}$ Despite this, it is often challenging to recruit personnel to the services, and it is estimated that one-third of the employees in ordinary health service do not have health education. ${ }^{34}$ de Bruin et al noted that making health services more familiar and homelike for older people should not be in contradiction with professionalism and adequate quality of care. ${ }^{21}$ In an early stage of dementia, prolongation of life and maintenance of daily function and activities are important aspects of care. Maintenance of function will also be a perspective in the moderate phase of the disease, although maximization of comfort will gradually take over. ${ }^{35}$ FDC is not only a place for activities in a positive environment, it is also a health service. Care farms cover a wide range of important aspects of care such as health promotion, maintenance of function, rehabilitation, and treatment. ${ }^{15}$ This is in line with the needs of people with dementia during the early and moderate stages of the disease.

The care environment and the activities offered in RDC services are poorly described in the literature. ${ }^{36,37}$ In Norway, most day care services $(74.7 \%)$ take place in a health care institution. The remaining services are located in settings such as a community house, a farm, or the person's own home. ${ }^{17}$ There are reasons to believe that the farm provides a special context for the day care service, as it is characterized by farm buildings, gardens, animals, and outdoor areas. The farm environment has been described as positive for the participants as it appears small scaled and homelike. ${ }^{21,38}$ Moreover, the presence of animals or cultivated land will affect what the participants see, smell, and experience. All the farms in our study reported that the participants spent time outdoors every day. However, there was a noteworthy difference in time spent outdoors, during both summer and winter, between FDCs with small and medium-sized groups (Table 3). In a Dutch study investigating outdoor and indoor activities at both FDC and RDC, de Bruin et al found that participants in the FDC tended to spend more time outside because much of the work and activities at the farm were outdoors. ${ }^{25}$ Important activities took place outside, like going for a walk, wood working, or taking care of plants or animals. Activities that take place in a natural environment contribute to well-being. ${ }^{14,22,39}$ Førsund et al found that doing outdoor activities was central for the experience of meaning in life. Going for a walk in a familiar environment maintained a sense of coping and was connected to emotional well-being, prevention of loneliness, and being physically active. ${ }^{40}$ All the farms in our study described that they used the nearby cultural landscape for walking. Taking part in the local environment and community is essential for some people with dementia. ${ }^{40}$ Hendriks et al found that for people with dementia, nature influences the well-being and quality of life in several areas, such as relaxation, feeling fit, enjoying the beauty of nature, feeling useful, and recall memories. ${ }^{41}$ Hassink et al, explored the importance of animals at care farms, and found several potential benefits, e.g., animals made the day more meaningful, kept participants occupied, generated valued relationships, distracted people from their problems, facilitated customized care, and contributed to a welcoming environment. ${ }^{42}$ This reflects the literature describing being in nature and with animals as one of the health-promoting elements of FDC. ${ }^{18,21,43}$ Most of the FDCs in our study had animals in the farm. Gorman points out that animals can limit the therapeutic effect on the participants, as not all are comfortable with animals. ${ }^{44}$ However, the providers in our study described the relationship with the animals as exclusively positive for the attendants.

In addition to experiences related to nature, our study showed that one of the most important activities at the farm was social interaction. This was related to different activities, but first and foremost were the meals, and most of the farms served several meals a day. This is in accordance with other studies describing the meaning of the social interaction that is taking place during a meal. ${ }^{9,24,45}$ In a systematic meta-synthesis from 2016, Eriksen et al found that it is of importance for people with dementia to meet others in the same situation to feel equality, comfort, and safety. ${ }^{46}$

Strandenæs et al interviewed people with dementia attending Norwegian RDC services. The participants expressed that they had to adapt to the activities offered and that they would not expect the service to facilitate activities of their interest. ${ }^{24}$ By contrast, the providers in our study highlighted the possibility of tailoring the services to each participant. The diversity in activities, and indoor and outdoor surroundings, made it possible to facilitate for individual needs and social fellowship. A Dutch study described a higher 
variety in activities offered both indoors and outdoors in FDC services compared to RDC services. ${ }^{21,25}$

To tailor their service to the needs of each participant, the providers gathered oral and/or written information about each participant's life and perspective at the start. Personal knowledge about each person with dementia is essential for the perspective of person-centered care. ${ }^{47,48}$ By focusing on resources and potentials of the participant, the providers may facilitate activities and social settings based on their remaining capacities. ${ }^{21,49}$ Studies also emphasize the value of the written communication between the farm and the next of kin from each stay in the FDC. ${ }^{12}$ The loss in cognitive level (e.g., memory and language difficulties) affects the social functioning of people with dementia, ${ }^{3}$ and written information enriched the conversations at home. Additionally, it made it easy to deliver small messages that may support the identity and the influence of both next of kin and the people with dementia. ${ }^{12}$

\section{Strengths and limitation}

A strength of this research is that the survey covered 32 of the 33 farms offering FDC in Norway, and therefore gives a representative overview of the services. We also had access to additional information from a second survey study, which enriched our data. However, this study relied on confidence in the information reported by the providers at the farms. We did not perform any observational controls on the information about activities, routines, etc. Due to the limited number of farms, our findings cannot be generalized in statistical sense. Nevertheless, according to the purpose of this study we have described the nature of FDCs in Norway, and suggest that this knowledge can be of an international interest related to developing and evaluating FDCs and day care offers in general for people with dementia.

\section{Conclusion}

It is important to develop high-quality and easily adapted services for the increasing number of people with dementia in the future. The present study has described the nature of FDC in Norway. The services have similarities in terms of organization, daily structure, and personnel with health education to those located close to health care institutions. On the other hand, FDC represents a complementary service as it differs in the type of care environment with its wide range of activities and background of farm buildings, gardens, animals, and outdoor areas. This study has been conducted in a Norwegian context, but the findings could be of international interest for development of complementary day care services with activities for people with dementia. Understanding the nature of FDC raises question for further research on for whom this type of service might be beneficial, how the participants and next of kin experience and benefit from the service, and what is unique about the farm context as compared to RDC.

\section{Acknowledgments}

The study was funded by a grant from the Research Council of Norway (no. 255033/E50). The authors would like to thank the service providers in the FDCs for sharing their valuable experiences. We also thank researcher Brit Logstein at the Institute for Rural and Regional Research, and Liv Bjerknes Taranrød and Bjørnar Finnanger Garshol for important contribution during data collection.

\section{Disclosure}

The authors report no conflicts of interest in this work.

\section{References}

1. Engedal K, Haugen P, Nygård AM, et al. Demens. Fakta og utfordringer: Larebok [Dementia. Facts and Challenges: Textbook]. Tønsberg: Forlaget Aldring og helse; 2009. Norwegian.

2. WHO. Dementia: a public health priority. World Health Organization. 2012. Available from: http://www.who.int/mental_health/publications/ dementia_report_2012/en/. Accessed December 15, 2017.

3. Livingston G, Sommerlad A, Orgeta V, et al. Dementia intervention, prevention, and care. Lancet. 2017;390(10113):2673-2734.

4. Norwegian Ministry of Health and Care Services. Demensplan 2020 -Et mer demensvennlig samfunn [Dementia Plan 2020 - A more dementiafriendly society]. Oslo. 2015. Available from: https://www.regjeringen. no/en/dokumenter/dementia-plan-2020/id2465117/. Accessed December 15, 2017. Norwegian.

5. Mørk E. Hjemme så lenge som mulig [Home As Long As Possible]. Kongsberg-Oslo: Statistics Norway; 2013. Norwegian.

6. Stephan A, Bieber A, Hopper L, et al. Barriers and facilitators to the access to and use of formal dementia care: findings of a focus group study with people with dementia, informal carers and health and social care professionals in eight European countries. BMC Geriatr. 2018;18(1):131.

7. Ellen ME, Demaio P, Lange A, Wilson MG. Adult day center programs and their associated outcomes on clients, caregivers, and the health system: scoping review. Gerontologist. 2017;57(6):e85-e94.

8. Fields NL, Anderson KA, Dabelko-Schoeny H. The effectiveness and adult day services for older adults: a review of the literature from 2000 to 2011. J Appl Gerontol. 2014;33(2):130-163.

9. Rokstad AMM, McCabe L, Robertson JM, Strandenaes MG, Tretteteig S, Vatne S. Day care for people with dementia: a qualitative study comparing experiences from Norway and Scotland. Dementia (London). Epub 2017 Jan 1.

10. Rokstad AMM, Engedal K, Kirkevold Ø, Šaltyte Benth J, Barca ML, Selbæk G. The association between attending specialized day care centers and the quality of life of people with dementia. Int Psychogeriatr. 2016;29(4):627-636.

11. Norwegian Ministry of Health and Care Services. Demensplan 2015 -Den gode dagen [Dementia Plan 2015 - The good day]. Oslo. 2007. Available from: https://www.regjeringen.no/globalassets/upload/HOD/ Vedlegg/Omsorgsplan_2015/Demensplan2015.pdf. Accessed December 15, 2017. Norwegian. 
12. Strandli E, Skovdahl K, Kirkevold Ø, Ormstad H. Inn på tunet-et helsefremmende tilbud. En studie om ektefellers opplevelse med dagaktivitetstilbud for personer med demens [Care farming - a health promoting service. A study of spouses' experience of day-care services for people with dementia.] $J$ Cancer Res. 2016;2(3):202-211. Norwegian [with English abstract].

13. Norwegian Ministry of Local Government and Regional Development and Ministry of Agriculture and Food. Inn på tunet: Handlingsplan for 2013-2017. [Care farming - Action plan for 2013-2017] Oslo. 2013. Available from: https://www.regjeringen.no/no/dokumenter/inn-patunet/id735080/. Accessed December 15, 2017. Norwegian.

14. Hine RE, Peacock J, Pretty J. Care farming in the UK: Evidence and Opportunities. Report for the National Care Farming Initiative (UK) 2008. Available from: https://www.carefarminguk.org/resources/ research-publications/. Accessed December 15, 2017.

15. Haubenhofer DK, Elings M, Hassink J, Hine RE. The development of green care in Western European countries. Explore (NY). 2010;6(2):106-111.

16. Strandli E, Haugen PK, Jacobsen $\mathrm{S}$, et al. Den beste dagen på mange år... : Dagtilbud for personer med demens $i$ Grønn omsorg [The Best Day for Many Years .... Day Care for People with Dementia in Green Care]. Tønsberg: Forlaget Aldring og helse; 2007. Norwegian.

17. Gjøra L, Kirkevold Ø, Eek A. Nasjonal kartlegging av tilbudet til personer med demens 2014 : Demensplan 2015 [National Survey of the service for people with dementia 2014: Dementia Plan 2015]. Tønsberg: Forlaget Aldring og helse; 2015. Norwegian.

18. Pedersen I, Patil G, Berget B, Ihlebæk C, Gonzalez MT. Mental health rehabilitation in a care farm context: a descriptive review of Norwegian intervention studies. Work. 2016;53(1):31-43.

19. Pedersen I, Ihlebæk C, Kirkevold M. Important elements in farm animalassisted interventions for persons with clinical depression: a qualitative interview study. Disabil Rehabil. 2012;34(18):1526-1534.

20. Hassink J, Elings M, Zweekhorst M, van den Nieuwenhuizen N, Smit A. Care farms in the Netherlands: attractive empowerment-oriented and strengths-based practices in the community. Health Place. 2010;16(3):423-430.

21. de Bruin S, de Boer B, Beerens H, Buist Y, Veerbek H. Rethinking dementia care: the value of green care farming. J Am Med Dir Assoc. 2017;18(3):200-203.

22. Leck C, Upton D, Evans N. Growing well-beeings: the positive experience of care farms. Br J Health Phsycol. 2015;20(4):745-762.

23. Hemingway A, Ellis-Hill C, Norton E. What does care farming provide for clients? The views of care farm staff. NJAS. 2016;79:23-29.

24. Strandenæs MG, Lund A, Rokstad AMM. Experiences of attending day care services designed for people with dementia - a qualitative study with individual interviews. Aging Ment Health. 2017;22(6):1-9.

25. de Bruin S, Oosting SJ, Kuin Y, et al. Green care farms promote activity among elderly people with dementia. J Hous Elder. 2009;23(4): 368-389.

26. de Boer B, Hamers JP, Zwakhalen SM, Tan FE, Beerens HC, Verbeek $\mathrm{H}$. Green care farms as innovative nursing homes, promoting activities and social interaction for people with dementia. J Am Med Dir Assoc. 2017;18(1):40-46

27. Langørgen A, Løkken SA, Aaberget R. Gruppering av kommuner etter folkemengde og økonomiske rammebetingelser [Grouping of municipalities by population and economic conditions]. 2013. Available from: https://www.ssb.no/offentlig-sektor/artikler-og-publikasjoner/_attachment/225199?_ts=14ce4c230d0.Accessed December 15, 2017. Norwegian.

28. Norwegian Ministry of Health and Care Services. Lov om kommunale helse- og omsorgstjenester m.m. (helse- og omsorgstjenesteloven) §3-1 [The Act on Municipal Health and Care Services, etc. (Health and Care Services Act) §3-1]. Oslo. 2011. Available from: https://lovdata.no/dokucment/NL/lov/2011-06-24-30. Accessed December 15, 2017. Norwegian.

29. de Bruin S, Oosting S, Tobi H, Enders-Slegers MJ, van der Zijpp A, Schols JMG. Comparing day care at green care farms and at regular day care facilities with regard to their effects on functional performance of community-dwelling older people with dementia. Dementia. 2011;11(4):503-519.
30. Tretteteig S. Dagaktivitetstilbud. In: Tretteteig S, editor. Demensboka [Dementia book]. Tønsberg: Forlaget Aldring og helse; 2016:423-434. Norwegian.

31. Strandli E. Inn på tunet-dagaktivitetstilbud tilrettelagt for personer med demens. Nasjonal håndbok [Care farming - Day care services designed for people with dementia. National Manual]. Tønsberg: Forlaget Aldring og helse; 2016. Norwegian.

32. Johannessen A, Möller A. Experiences of persons with early-onset dementia in everyday life: a qualitative study. Dementia (London). 2013;12(4):410-424.

33. Norwegian Ministry of Health and Care Services. Lov om kommunale helse- og omsorgstjenester m.m. (helse- og omsorgstjenesteloven) §4-1 [The Act on Municipal Health and Care Services, etc. (Health and Care Services Act) §4-1]. Oslo. 2011. Available from: https:/lovdata. no/dokument/NL/lov/2011-06-24-30. Accessed December 15, 2017. Norwegian.

34. Gautun H, Bratt C. Bemanning og kompetanse i hjemmesykepleien og sykehjem [Personnel and competence in home health care and nursing homes.]. Velferdsforskningsinstituttet NOVA, Høgskolen i Oslo og Akershus. 2014. Available from: http://www.hioa.no/Om-HiOA/ Senter-for-velferds-og-arbeidslivsforskning/NOVA/Publikasjonar/ Rapporter/2014/Bemanning-og-kompetanse-i-hjemmesykepleien-ogsykehjem. Accessed December 15, 2017. [Norwegian].

35. van der Steen JT, Radbruch L, Hertogh CM, et al; European Association for Palliative Care (EAPC). White paper defining optimal palliative care in older people with dementia: a Delphi study and recommendations from the European Association for Palliative Care. Palliat Med. 2014;28(3):197-209.

36. Manthorpe J, Moriarty J. Examining day centre provision for older people in the UK using the Equality Act 2010: findings of a scoping review. Health Soc Care Community. 2014;22(4):352-360.

37. Tretteteig S, Vatne S, Rokstad AM. The influence of day care centres for people with dementia on family caregivers: an integrative review of the literature. Aging Ment Health. 2016;20(5):450-462.

38. Verbeek H, van Rossum E, Zwakhalen SM, Kempen GI, Hamers JP. Small, homelike care environments for older people with dementia: a literature review. Int Psychogeriatr. 2009;22(2):252-264.

39. Sempik J. Green care and mental health: gardening and farming as health and social care. Ment Health Soc Incl. 2010;14(3):15-22.

40. Førsund LH, Grov EK, Helvik AS, Juvet LK, Skovdal K, Eriksen S. The experience of lived space in persons with dementia: a systematic meta-synthesis. BMC Geriatr. 2018;18(1):33.

41. Hendriks IH, van Vliet D, Gerritsen DL, Dröes RM. Nature and dementia: development of a person-centered approach. Int Psychogeriatr. 2016;28(9):1455-1470.

42. Hassink J, de Bruin SR, Berget B, Elings M. Exploring the role of farm animals providing care at care farms. Animals (Basel). 2017; 7(6):E45.

43. Anderson KA, Chapin KP, Reimer Z, Siffri G. On fertile ground: an initial evaluation of green care farms in the United States. Home Health Care Serv Q. 2017;36(1):1-15.

44. Gorman R. Therapeutic landscapes and non-human animals: the roles and contested positions of animals within care farming assemblages. Soc Cult Geogr. 2017;18(3):315-335.

45. Keller HH, Martin LS, Dupuis S, R G, Edward HG, Cassolato C. Mealtimes and being connected in the community-based dementia context. Dementia. 2010;9(2):191-213.

46. Eriksen S, Helvik AS, Juvet LK, Skovdahl K, Førsund LH, Grov EK. The experience of relations in persons with dementia: a systematic meta-synthesis. Dement Geriatr Cogn Disord. 2016;42(5-6):342-368.

47. Kitwood T. En revurdering af demens- personen kommer i første rakke [A reassessment of dementia - The person comes first]. 7th ed. København: Munksgaard; 1999. Danish.

48. Brooker D. What is person-centred care in dementia? Clin Gerontol. 2004; $13: 215-222$

49. de Vugt M, Dröes RM. Social health in dementia. Towards a positive dementia discourse. Aging Ment Health. 2017;21(1):1-3. 
The Journal of Multidisciplinary Healthcare is an international, peerreviewed open-access journal that aims to represent and publish research in healthcare areas delivered by practitioners of different disciplines. This includes studies and reviews conducted by multidisciplinary teams as well as research which evaluates the results or conduct of such teams or health care processes in general. The journal covers a very wide range of areas and welcomes submissions from practitioners at all levels, from all over the world. The manuscript management system is completely online and includes a very quick and fair peer-review system. Visit http://www.dovepress.com/ testimonials.php to read real quotes from published authors. 